\title{
Nationale tv-strategier under det arabiske forår
}

\author{
Af Ehab Galal
}

\begin{abstract}
:
Since the beginning of the uprisings in Tunisia, Egypt, Yemen, Libya and Syria in winter and spring 2010-2011, the national Arab televisions (state or private owned) have found themselves in a challenging situation. They have been forced to find a balance between traditional loyalties to the ruling power and loyalty towards journalistic standards of critical and objective coverage of popular national uprisings. Gradually, during the periods of uprisings, television has changed its coverage in accordance with the local national development of the revolutionary movements. This paper will analyse such changes of coverage. The basis of the analysis is the coverage of the uprisings in Egyptian television, primarily in news programs, in the period January - August 2011. The general argument of the paper is that Egyptian television in this period has gone through six phases in their coverage. In the paper the phases will be explored and illustrated by examples.
\end{abstract}

Det arabiske forår, som er blevet fællesbetegnelsen for de politiske opstande i Tunesien, Egypten, Yemen, Libyen, Bahrain og Syrien i vinteren 2010 og foråret 2011 ændrede ikke kun det politiske landskab i de involverede lande. Det udfordrede også både statslige og privatejede nationale tv-kanalers måde at dække begivenheder, der direkte handlede om det politiske regimes overlevelse. Selv om fjernsynsmediet i lande som Egypten og Tunesien er gået igennem en vis grad af liberalisering de sidste tolv til femten år, har det stadig - indtil begyndelsen af opstandene - været karakteriseret ved en høj grad af loyalitet over for regimet. Tv har været statens og regimets redskab til at udbrede deres fortolkning af den politiske virkelighed og herigennem sikre folkets loyalitet (Abu-Lughod 2005; Rugh 2004). Således har de nationale tv-kanaler i vid udstrækning bevaret den stærke loyalitet over for den herskende magt i de forskellige arabiske lande, uanset at graden af censurering varierer og sanktioneres forskelligt i de forskellige lande. Spørgsmålet er, hvad tv gør ved denne loyalitet, når den herskende magt først udfordres, derefter rystes, og i sidste ende væltes? Hvordan dækker tv begivenhederne, og hvordan afspejler dækningen den igangværende politiske kamp?

(C) Forfatteren og Tidsskrift for Islamforskning, ISSN 1901-9580, publiceret 1-03-2013 
Disse spørgsmål vil i denne artikel blive belyst gennem en analyse af tv-dækningen af den egyptiske opstand, som den udfoldede sig fra den første store folkelige demonstration den 25. januar 2011 til præsident Mubarak trådte tilbage som resultat af protesterne den 11. februar 2011. ${ }^{1}$ Grundlaget for analysen er tv-dækningen af opstanden, primært i nyhedsudsendelser og debatprogrammer på statslige og privatejede tv-kanaler. Artiklens overordnede argument er, at nationalt tv i perioden har haft overordentligt vanskeligt ved at finde ud af, hvilket ben de skulle stå på. Ser man nærmere på de forskellige strategiske greb, som tv-dækningen har taget $\mathrm{i}$ anvendelse, viser der sig et mønster, hvor de nationale tv-kanaler ikke har været frontkæmpere for forandringer. Snarere har de et langt stykke af vejen været bagstræberiske i den forstand, at de længst muligt har opretholdt loyaliteten over for regimet. Således fremstår de som modsætninger til de sociale og transnationale medier, som i langt højere grad synes at have fungeret som frontløbere for den politiske opstand (El-Nawawy and Khamis 2012; Root 2012). En sådan konkurrence og konflikt i mediedækningen kan, som Gadi Wolfsfeld (1997) argumenterer for, ses som en del af et større og mere vigtigt konkurrenceparameter for politisk kontrol blandt politiske modstandere. I forlængelse af Wolfsfelds teoretiske tilgang vil jeg belyse, hvordan tvdækningen afspejler ændringen i politisk kontrol, snarere end at den bliver årsagen til politisk forandring. Jeg vil i det følgende først give en kort introduktion til dette teoretiske perspektiv, for dernæst at præsentere og analysere seks forskellige strategier, som blev taget $\mathrm{i}$ brug af nationale tv-kanaler under dækningen af den egyptiske opstand.

\section{Fjernsyn som revolutionær kraft eller revolution som grundlag for ny tv-dækning?}

Lanceringen af den qatarianske sattelit-tv-kanal al-Jazeera i 1996 fik mange, især vestlige iagttagere til at fremhæve de potentielt demokratiserende kræfter i liberale og transnationale medier i den arabiske verden (Alterman 1998; Lynch 2006; Miles 2005). Der er næppe tvivl om al-Jazeeras positive indflydelse på den kritiske offentlige debat i den arabiske verden. I forhold til den egyptiske opstand er spørgsmålet dog, om det var fjernsynet, der forårsagede de politiske ændringer, eller om det snarere var de politiske forandringer, der dikterede en ny tv-dækning? Dette spørgsmål rejser både en generel teoretisk

(C) Forfatteren og Tidsskrift for Islamforskning, ISSN 1901-9580, publiceret 1-03-2013 
diskussion og en diskussion af den konkrete egyptiske case. Denne artikels fokus er på den egyptiske case.

Wolfsfeld (1997) introducerer, hvad han definerer som en politisk konkurrencemodel (political contest model). Hans hovedargument er, at kampen om tv-dækningen skal ses som et element i konkurrencen mellem politiske modstandere for at opnå politisk kontrol (ibid.). Det betyder samtidig, at tv-institutionen ikke skal ses som en politisk revolutionær kraft i sig selv, blot fordi vi har set tv blive involveret som aktør i revolutionen. Snarere vil tv-dækningen ofte afspejle den aktuelle politiske situation, som til hver en tid er resultatet af politiske eliters kamp om magten. På lignende vis som Wolfsfeld, har Naomi Sakr argumenteret for, at de nye arabiske transnationale satellitkanaler afspejler de politiske forandringer, konflikter og omlægning af den herskende elite. Pointen er, at det er de herskende eliters politiske og $\varnothing$ konomiske alliancer og prioriteringer, der har indflydelse på form og orientering af de arabiske medier (Sakr 2001, 2005, 2007).

I dette perspektiv har de egyptiske magthavere siden uafhængigheden i 1952 brugt tv til opbygningen af en national loyalitet og identitet (Abu-Lughod 2005). Tv har samtidig været tæt knyttet til og censureret af magthaverne og har derfor været et loyalt talerør og støtte for de skiftende nationale og politiske diskurser (ibid.; Sakr 2007). Det er derfor ikke overraskende, at man, da opstanden begyndte, kunne se tv fastholde loyaliteten over for regimet. Det betyder, at de nationale tv-kanaler de facto indgik som politiske medspillere ved indledningsvis at nedtone eller minimere opstandenes betydning. Modsætningen hertil var en kanal som al-Jazeera, der fra begyndelsen gav plads til en intensiv dækning af opstanden, ikke blot i Egypten, men også i de andre lande ramt af opstande. AlJazeera, al-Arabiya og andre transnationale tv-stationer som CNN påtog sig generelt $\mathrm{i}$ deres dækning og drøftelser rollen som 'advokater' eller fortalere for demonstranterne. I deres dækning præsenterede de forhold, der kan have mobiliseret andre aktører til at deltage i demonstrationerne (se fx Campbell og Hawk 2012). På den måde spillede de en vigtig rolle ved at tilbyde en platform, hvorfra demonstranter og sympatisører kunne kommunikere og fremme deres budskaber under opstanden. En sådan platform var de

(C) Forfatteren og Tidsskrift for Islamforskning, ISSN 1901-9580, publiceret 1-03-2013 
nationale tv-kanaler til gengæld meget sent om at tilbyde aktivisterne. Denne mediestrategiske forskel er tæt forbundet med de omtalte transnationale og nationale kanalers forbindelse til diverse politiske eliter og viser, at adgangen til mere pluralistiske medier ikke i sig selv genererer protester. Pluralismen er til gengæld grundlaget for, at der bliver plads til flere politiske stemmer og dermed muligheden for at kommunikere til et bredere publikum inden og uden for nationen. Af samme grund har kampen om og kontrollen over tv været et vigtigt element under opstandene, hvilket på egyptisk tv førte til en vifte af strategier og et kursskifte på 180 grader under den 18 dage lange opstand.

\section{Strategi eller taktik?}

Opstandens relativt korte forløb rejser spørgsmålet om betydningen af, om der er tale om dækningen af en specifik og relativ kortfattet konflikt, eller om der er tale om langsigtede ændringer over en længere periode. Forskellen på at agere i en politisk sammenhæng, hvor forandring sker langsomt, eller i en situation, hvor den politiske magt ændres på 18 dage, kræver en nuancering af spørgsmålet om tv-mediets politiske strategier. Netop begrebet strategi bruges ofte til at referere til handlinger rettede mod mere langsigtede mål. Disse kan være ganske vanskelige at opstille, hvis det politiske landskab på kort tid eroderes. Michel de Certeaus begrebsliggørelser af forskellen på strategi og taktik kan være analytisk brugbare i denne sammenhæng (Certeau 1984). Strategiens langsigtede mål som styrende for ens handling knytter sig til Certeaus forståelse af beherskelsen af 'stedet' som afgørende for strategiens udfoldelse. Hvis man har magt til at definere og organisere stedet, har man den tilstrækkelige viden til at (be)herske dette og på dette grundlag opstille strategier for fastholdelsen af denne magt over længere tid. Taktik tilhører til gengæld dem, der ikke sidder med definitionsmagten over stedet, og er derfor mere kortsigtet. Taktik handler om at navigere på magtens præmisser og forsøge at manipulere eller ændre stedets betydning. Taktik virker dermed i kraft at være kortvarig og er de ikke magtfuldes redskab (Certeau 1984: 34-37). Dette begrebspar bliver relevant i analysen af de egyptiske tv-kanalers dækning af opstandene, fordi kampen om beherskelsen af rummet $\mathrm{i}$ form af den nationale politiske offentlighed er opstandens centrale magtkamp.

(C) Forfatteren og Tidsskrift for Islamforskning, ISSN 1901-9580, publiceret 1-03-2013 
Symbolsk finder denne kamp sted som en kamp om 'Tahrir'-pladsen, og det er derfor heller ikke overraskende, at mediernes dækning netop kredser om, hvem og hvad der behersker de offentlige rum i Egypten. Er der tale om ballade- og uromagere eller frihedssøgende repræsentanter for folket? Og hersker der faktisk normale tilstande i det meste af Egypten, og er det dermed stadig regimet, der sidder på retten til at definere rammerne for den offentlige politiske orden? Spørgsmålet er, hvad de nationale tv-stationer gør, efterhånden som regimets magt over det nationale rum eroderes og dermed den strategiske handlen umuliggøres. Jeg vil i det følgende pege på seks strategier, som de egyptiske tvkanaler bringer i anvendelse under opstanden. Selv om jeg overordnet kalder dem strategier, får de under opstanden mere og mere karakter af taktikker. Af samme grund er det svært entydigt at tidsfæste disse seks strategiske praksisser. Selv om de overordnet set synes at afløse hinanden, som situationen udvikler sig, overlapper de også hinanden og afslører dermed, at den langsigtede strategi erstattes af, hvad der til tiden fremstår som en temmelig desperat søgen efter taktisk fodfæste.

\section{Fra tavshed til U-vending: Seks strategier for tv-dækning}

Da demonstrationen mod politivold, der skulle afholdes på den nationale dag for fejring af politiet den 25. januar, blev annonceret, var der ingen, der forventede, at det ville blive begyndelsen på regimets fald. Folk var blevet opfordret til at deltage bl.a. via Facebook, Twitter og forskellige blogs, og demonstrationen voksede stødt i løbet af dagen. Dagen blev døbt Vredens dag, og på et tidspunkt blev slagord om en Tunesien-løsning dominerende med henvisning til den tunesiske præsidents fald på grundlag af et folkeligt krav. Fire personer døde under sammenstødene mellem politi og demonstranter, hvoraf en var fra sikkerhedsstyrkerne. Mobiltelefonnettet blev lukket ned af staten og kom først op at køre igen sent om aftenen. Fra dag ét blev kampen om kontrollen over og adgangen til medierne således et helt afgørende element i konfliktens udvikling. Det nationale tv's rolle kan aflæses i de anlagte strategier for dækning af begivenhederne.

(C) Forfatteren og Tidsskrift for Islamforskning, ISSN 1901-9580, publiceret 1-03-2013 


\section{1: Tavshed}

Da demonstranterne stod på Tahrir den 25. januar forblev de nationale tv-kanaler tavse. Nyhedsprogrammerne undlod simpelthen at tillægge demonstrationen betydning gennem tavshed om og fortielse af, hvad der forgik. Disse fortielser blev sat i perspektiv af, at satellit-kanaler som al-Jazeera i de selvsamme minutter, som det nationale tv forbigik begivenhederne med tavshed, viste billeder af de mange demonstranter, der samledes. På samme måde som at lukke mobilnettet, var strategien at lukke af for viden og adgang til viden om, hvad der foregik. Med de Certeaus terminologi kan det ses som forsøget på entydigt at fastholde definitionsretten og magten over rummet, i dette tilfælde Tahrirpladsen, og hvad dette kan bruges til. Hvor demonstranterne udnyttede demonstrationen som et taktisk mulighedsrum, var regimet og de nationale medier på dette tidlige tidspunkt først og fremmest opsat på at opretholde det system, de mente at beherske, og som sikrede dem en strategisk fordel.

\section{2: Fornagtelse}

I de følgende dage eskalerede demonstrationerne med yderligere sammenstød og dødsfald til følge. Internettet blev afbrudt i et tidsrum den 26. januar og helt lukket ned sammen med mobilnettet den 27. januar. De nationale tv-kanaler ignorerede stadig, hvad der foregik. Demonstrationerne kulminerede fredag den 28. januar med store demonstrationer i flere byer, nedbrændte politistationer i Alexandria og andre byer, nedbrænding af det nationale partis hovedkvarter i Cairo og i andre byer. Hæren gik på gaden, og der blev indført undtagelsestilstand og udgangsforbud mellem klokken 16 og 8. Indenrigsministeriet frigav adskillige kriminelle $\mathrm{i}$ et forsøg på at skabe kaos og skræmme befolkningen. Adskillige demonstranter blev dræbt eller såret. Samme aften talte Mubarak på tv om at udskifte regeringen.

Det nationale tv reagerede ved at benægte opstandens omfang og de fortsatte demonstrationer. I modsætning til den indledningsvise tavshed tog nyhedsprogrammerne temaet op, samtidig med at de afviste det som et reelt eksisterende problem. Herfor argumenterede de ved at vise billeder af fredelige gader uden tilstedeværelse af eventuelle demonstranter

(C) Forfatteren og Tidsskrift for Islamforskning, ISSN 1901-9580, publiceret 1-03-2013 
eller sammenstød. Tv-kommentatorerne forklarede, at alt var fredeligt og roligt i gaderne. Et eksempel var, da den egyptiske tv-studievært ringede op til den lokale borgmester i forskellige byer og udspurgte dem om situationen. På skift bekræftede borgmestrene, hvordan alt i deres by var roligt og fredeligt. Borgmesteren i Port Said sagde bl.a.: "Her i Port Said er alt fredeligt. Der sker ingenting. Dette er Egypten. Det er sådan egyptere opfører sig. Egypterne er rolige og fredelige mennesker.” Igen bliver regimets kontrol over rummet et vigtigt budskab til de, der tror, at de kan ændre på spillereglerne. Samtidig understreges, at forudsætningen for at kunne udnytte spillets regler er loyalitet over for regimet, som kræver, at man agerer som 'sande egyptere'. Ethvert udtryk for opstand er således imod 'egyptiskhed'. Igen modsvares det fordrejede billede af regimets kontrol over det nationale rum gennem al-Jazeeras direkte streaming af billeder fra massedemonstrationerne.

\section{3: Indrømmelse men mistanksom}

Den 29. januar udpegede Mubarak for første gang, siden han overtog magten i 1981, en vicepræsident. Det var Omar Suliman, som på det tidspunkt havde været chef for efterretningstjenesten i ca. 20 år. Også en ny statsminister blev udpeget. Internettet var stadig afbrudt, mens mobilnettet kom op at køre igen. Privatpersoner oprettede vagtværn i deres boligområder som beskyttelse mod kriminelle, der ifølge rygterne stod bag en bølge af indbrud og overfald. Regeringen opretholdt også udgangsforbuddet. Med indrømmelserne fra Mubarak blev det vanskeligere for de nationale medier at opretholde illusionen om, at der intet for alvor var i gære. Men i stedet for at etablere en kritisk dækning af demonstranternes politisk legitime krav og reaktionerne herpå, brugte det nationale tv en strategi i de følgende dage, der fremstillede opstanden som illegitim. For det første fik seerne at vide, at antallet af demonstranter var meget lavt. For det andet blev disse samtidig miskrediteret ved at fremstille dem som unge ballademagere eller forrædere, der blev købt af fremmede magter for at ødelægge landet.

Således bragte den egyptiske statskanal ESC (Egyptian Satellite Channel) den 3. februar 2011 historien om en soldat, det tilsyneladende var gået over på demonstranternes side.

C F Forfatteren og Tidsskrift for Islamforskning, ISSN 1901-9580, publiceret 1-03-2013 
Historien blev fremstillet ved bl.a. at henvise til en transmission fra den arabisksprogede amerikanske satellitkanal, al-Hura. Den viser et klip med en officer på Tahrir-pladsen, der blev set i venlig interaktion med demonstranter. Klippet giver indtryk af, at han kunne have valgt side med demonstranterne. Den mandlige studievært på ESC præsenterer fra begyndelsen klippet som mistænkeligt. Umiddelbart efter siger den kvindelige studievært: "glem ikke, at der er nogle af de fabrikker og butikker, der sælger disse uniformer, som er blevet plyndret, hvilket hæren har bekræftet." Den underforstående pointe var, at soldaten på klippet ikke var en ægte soldat, men snarere enten en kriminel eller en med kontakter til kriminelle. Et interview med General Husam Suilam over telefonen skulle kaste yderligere lys over sagen. Suilam siger om manden i soldateruniformen på Tahrir: "Denne mand skal straffes ved domstolen. Først og fremmest er det ikke den nuværende uniform." Da studieværten beder ham om at uddybe, antyder han, at manden var en falsk soldat, iført en civil skjorte (uagtet, at skjorten faktisk overhovedet ikke var synlig på klippet) og en forældet og falsk uniform, og han tilføjer: "Du kan se den måde, han sidder blandt folket. Han sidder på en beskidt måde. Det er en mistænkelig måde, han sidder på. Målet med disse kanaler (han henviser til al-Hura) er at fortælle verden, at nogen fra hæren nu har forenet sig med det muslimske broderskab og demonstranterne. Det er et mål for disse kanaler. Det er så indlysende at gennemskue deres mål, selv for et lille barn. Målet er at sige, at nogen soldater forlod hæren og blev tilknyttet demonstranterne."

Programmet fortsatte mistænkeliggørelsen af, hvad der foregik, ved at henvise til, at der blandt demonstranterne var nogen, der lignede udlændinge. Disse påstande bestyrkede seerne yderligere, da de kunne ringe ind for at ytre deres mening om opstandene og om, hvad der foregik. En af de seere, som ringer ind, er angiveligt lægelig leder af Sankt Anglo hospital. Han bliver spurgt om de sårede, og om de alle var egyptere, hvilket han bekræfter. Men så fortsætter han med at fortælle om nogle mystiske opkald fra den franske ambassade, der $\emptyset$ nskede at sende en patient til behandling, og om en patient fra Irland, der dukkede op samme dag, hvilket lægen fremstiller som virkelig mærkeligt, fordi han ankom sammen med repræsentanter fra sin ambassade. Efterfølgende kom politiet og udspurgte ham og tog ham med sig efter behandlingen. Lægen giver ikke nogen forklaring, men fortsætter med at fortælle om et andet mystisk opkald fra en kvinde, der ringede fra

(C) Forfatteren og Tidsskrift for Islamforskning, ISSN 1901-9580, publiceret 1-03-2013 
et engelsk nummer, men hævdede at ringe fra Egypten. Hun havde en levantinsk dialekt og præsenterede sig som tilknyttet ABC nyhedsbureau. Hun ønskede at lave et interview med en læge, og han forklarer: ”Jeg nægtede at tale med hende. Jeg var bekymret. I den sidste periode har I talt i tv om, at der har været indblanding fra udlandet og fra udlændinge. Jeg siger, dette er sandt.” Den kvindelige studieværts fortsætter indslaget ved at fjerne ansvaret fra kanalen og lægge det over på 'folket' som 'øjenvidner': 'Det er folk på Tahrir-pladsen, der siger det.” Og den mandlige studievært fortsætter med at forsvare kanalens position ved at sige: "Tv transmitterer blot, hvad der sker, - transmitterer hvad der sker. Vi har ikke peget på en særlig retning. Vi refererer blot folk, der gør?” Og den kvindelige studievært tilføjer: "Vi har vist en masse billeder med udlændinge på Tahrir." Lægen bekræfter og fortsætter med at antyde, at den irske patient var ankommet præcis den 25. januar fra udlandet kun for at kæmpe og formentligt opmuntret af fremmede magter. Anklagen bliver aldrig sagt direkte, men fremlagt som en oplagt fortolkning. På samme tid som lægen er i telefonen, viser kanalen klip fra Tahrir pladsen med en blond kvinde. En yderligere miskreditering af opstanden skete gennem mistænkeliggørelsen af både den udbredte støtte blandt egyptere i udlandet og af de internationale mediers dækning heraf. Således leverede samme program et interview via telefon med en egyptisk forretningsmand, der ringede fra Thailand. Han fortalte om lokale egyptere, der angiveligt blev tilbudt 200 kroner af kanalen al-Jazeera English for at demonstrere foran den egyptiske ambassade.

Så mens endnu en million-demonstration finder sted fredag den 4. februar med symbolske billeder af kristne egyptere, der beskytter muslimske egyptere, mens de beder, bekræfter egyptiske medier rygterne om, at al-Jazeera i det skjulte arbejder for helt at ødelægge Egypten. Det er bl.a. den private kanal al-Mihwar², der i programmet '48 timer' bringer dette rygte til torvs.

Indrømmelserne af, at demonstranterne trods alt har fået politiske ændringer på banen, krydret med mistænkeliggørelsen af hvem det egentlig er, der definerer det nye politiske rum og dermed muligheden for at beherske det, afspejler generelt regimets strategi i dagene, der følger efter den 28. januar. I denne periode opretholdes udgangsforbuddet, in-

(C) Forfatteren og Tidsskrift for Islamforskning, ISSN 1901-9580, publiceret 1-03-2013 
ternettet lukkes ned, ligesom mere militær sendes på gaden den 30. januar. Samme dag får al-Jazeera derudover forbud mod at sende via den egyptiske satellit Nilesat, og den 1. februar standses al togtrafik for at forhindre egyptere fra alle dele af landet at komme frem til Tahrir-pladsen. Parallelt med disse begrænsninger af det offentlige rum, opfordrer Mubarak til forhandling med oppositionen, og den 1. februar holder han en tale til nationen, hvor han meddeler, at han ikke stiller op igen som præsident. Man kan sige, at både tv's og regimets ageren kan ses som en kamp for at opretholde grundlaget for magtens strategiske overlegenhed. Til gengæld afspejler indrømmelserne, at de er tvunget til taktiske greb i forsøget på at fastholde status quo. Selv om mistænkeliggørelsen af 'udefrakommende' og forhindring af adgang til viden ikke er en ny strategi i egyptisk politik, fremstår iscenesættelsen mere og mere tragikomisk i lyset af de store folkelige demonstrationer. Den gamle strategi knyttet til en specifik politisk virkelighed bliver sværere at få til at fungere i det nye politiske felt. Når journalisterne begynder at forsvare deres dækning med henvisning til øjenvidner, kan det ses som et taktisk forsøg på at navigere mellem den gamle og nye politiske virkelighed.

\section{4: Tilsyneladende imødekommenhed}

Mens 'kamelslaget' den 2. februar kunne ses som regimets desperate fors $\emptyset \mathrm{g}$ på at opretholde magten over rummet, blev massedemonstrationen fredag den 4. februar beviset på, at det ikke lykkedes. En vis accept af dette faktum spredte sig til de egyptiske tv-kanaler i tidsrummet efter. Der skete en gradvis, generel anerkendelse af den politiske kamp, der var grundlaget for demonstrationerne, og af en opfattelse af demonstranternes krav som legitime. Denne anerkendelse indebar dog ikke en fuld accept af de anvendte midler eller af de involverede aktører. Igen blev en række strategier i form af framing og retorik anvendt af nyhedsværter. For det første blev især de unge aktivister fremhævet, og deres initiativ og krav om reformer blev rost, samtidig med at de for det andet blev fremstillet som små og naive børn. For det tredje blev det gjort klart, at de nu burde være tilfredse, da de havde opnået deres mål, hvilket igen for det fjerde førte til den besked, at de nu havde gjort tilstrækkeligt. De blev opfordret til at gå tilbage til deres uddannelse og overlade resten til de ældre og mere erfarne. En række gæster, eksperter og unge blev inviteret

(C) Forfatteren og Tidsskrift for Islamforskning, ISSN 1901-9580, publiceret 1-03-2013 
ind i studiet. De unge deltagere bekræftede, at de deltog i demonstrationerne i begyndelsen. De bekræftede alle, at de ændringer, der var opnået gik i den rigtige retning, og de priste staten og roste Mubarak for at have lyttet. Samtidig miskrediterede de dem, der stadig demonstrerede, og som ifølge dem var købt af fremmede magter for at ødelægge Egypten. Hvad, der gjorde denne strategi anderledes og adskilte sig fra den foregående, var, at to af de unge aktivister, der stadig fandt grunde til at fortsætte kampen også blev inviteret ind i studiet. Dette skete dog meget sent om aftenen efter midnat. Det, der karakteriserede denne strategi, var altså en imødekommenhed over for demonstranterne i fuldstændig samme udstrækning, som staten har vist imødekommenhed fx gennem Mubaraks løfte om reformer og om ikke at stille op igen. Men tv-kanalerne strakte sig ikke længere end det, eller bød på en egentlig kritisk dækning af begivenhederne.

\section{5: En U-vending}

Den 10. februar 2011 afholdt militærkomitéen et møde uden Mubaraks tilstedeværelse. Demonstranterne krævede stadig Mubaraks afgang. Lige før midnat holdt Mubarak en tale, hvor han insisterede på at blive siddende som præsident, men overlod alle magtbeføjelser til vicepræsidenten. Dette tilfredsstillede ikke demonstranterne, og efter en række offentlige udtalelser med løfter til oppositionen og demonstranterne fra hærkomitéen i løbet af dagen den 11. februar, holder Suliman om eftermiddagen en tale, hvor han accepterede Mubaraks beslutning om at trække sig helt fra posten som den egyptiske præsident. Magten blev midlertidigt givet videre til hærkomitéen

Først efter Mubaraks endelige tilbagetræden udførte det nationale tv, hvad bedst kan kaldes en taktisk U-vending. Denne U-vending blev for det første gjort entydig symbolsk på egyptisk stats-tv gennem, idet gamle journalister og studieværter blev fjernet fra skærmen og helt nye ansigter fremtonede. . De tidligere journalister kom til at fremstå som repræsentanter for den utroværdige dækning, som indtil da havde fundet sted. For det andet ændredes retorikken, således at begreber som revolution og revolutionær erstattede begreber som forræder ('Amil). For det tredje begyndte den egyptiske statskanal at transmittere direkte via en permanent korrespondent fra Tahrir-pladsen, samtidig med at kanalen, for det fjerde, transmitterede en række interviews med demonstranter, der nu blev 
kaldt sønner af revolutionen (Awlad as-Saorah). For det femte blev unge mennesker, der støttede revolutionen, inviteret ind i studiet for at fortælle om deres krav, forventninger og håb. Tv-dækningen afspejler således det grundlæggende skift i kampen om magten.

\section{6: At slå plat eller krone igen og igen}

Efter det endelige fald af regimet var landsdækkende tv fanget i en situation, hvor de skulle finde ud af, hvilke af de politiske aktører, der ville komme til at vinde den politiske magtkamp. Med andre ord var nationalt tv fanget mellem den traditionelle rolle som støtter af det autokratiske styre, som stadig til en vis grad opretholdt magten, og de nye kræfter, som det følte sig tvunget til at give plads til for ikke helt at miskreditere sig selv. Således forsøgte nationalt TV på dette tidspunkt at tilbyde plads til langt flere forskellige meninger og aktører. Der var dog stadig begrænsninger, da nationalt TV forventede, at nye aktørers udtalelser skulle præsentere sig på en civiliseret måde og inden for rammer, hvor man kunne være uenig, men hvor man samtidig ikke direkte afviste den herskende magts diskurs. Et eksempel på disse begrænsninger er fra anden halvdel af juli, hvor den nye herskende magt i Egypten beskyldte 6. april-bevægelsen for at være forrædere, fordi de havde fået $\varnothing$ konomisk st $\varnothing t t e$ fra udlandet, og fordi nogle af dens medlemmer angiveligt havde været på træningslejr i Serbien. Anklagen faldt, da bevægelsen fortsatte med at demonstrere, protestere, og stå ved deres krav og fastholde, at de stadig ikke havde opnået deres mål. Idet nationalt tv henviste til den udenlandske indflydelse, blev bevægelsens motiv præsenteret som mistænkeligt, og denne diskurs blev fremmet yderligere i debatprogrammer, hvor de fleste var imod økonomisk støtte fra udlandet. De, der havde modtaget en sådan form for støtte, blev dermed præsenteret som forrædere. Imidlertid blev medlemmer af bevægelsen og sympatisører også inviteret i studiet for at diskutere anklagen. Det var dog stadig dem med den samme dagsorden som den nye herskende magt (det regerende militære råd), der fik mest taletid. Desuden blev den samme miskreditering fremsat i en statstransmitteret fredagsbøn to dage efter, at lederen af det regerende militære råd havde rejst spørgsmålet om udenlandsk infiltration. 
Temaet om den udenlandske infiltration var dominerende på tv indtil retssagen mod Mubarak og den tidligere indenrigsminister begyndte. Derefter gik denne debat så helt i sig selv igen for en tid, da israelske fly dræbte en egyptisk officer og sårede to soldater ved den egyptisk-israelske grænse den 18. august. Disse begivenheder gjorde, at egypterne fik mulighed for at stå sammen mod en anden fjende. Således gjorde 6. april-bevægelsen brug af konflikten til at legitimere sig selv. Mange medlemmer af bevægelsen demonstrerede $\mathrm{i}$ en uge foran den israelske ambassade, og det egyptiske tv præsenterede pludselig forholdet til Israel, som om det havde været blandt demonstranternes vigtigste principsager. Tv-dækningen kom samtidig til at fremstå som et forsøg på fra det regerende militære råd at flytte modstandernes opmærksomhed væk fra at kritisere deres politik. Situationen afspejler, at det nationale tv i slutningen af august og dermed næsten et halvt år efter revolutionsdagene på Tahrir stod i en situation, hvor resultatet af den politiske magtkamp stadig var uforudsigelig. Strategien var på dette tidspunkt stadig usikker, og de taktiske evner forblev centrale fra situation til situation. Tv-dækningen kom derfor til dels til at ligne en konstant slåen plat eller krone tæt forbundet med vurderingen af de forskellige politiske kræfters styrker i konkrete situationer.

\section{Konklusion}

Den politiske udvikling under opstanden i Egypten i perioden fra 25. januar til 11. februar satte de nationale tv-kanaler i et strategisk dilemma. Efterhånden som regimets magt $\mathrm{i}$ stigende grad blev destabiliseret og til sidst gik i opløsning (i dets daværende form), måtte nationalt tv benytte sig af både strategier og taktikker. Nationalt tv bevægede sig i denne proces fra en traditionel strategi, hvor de som loyale over for magten manøvrerede strategisk sikkert, til en situationsbåret taktik, som endte med at udstille deres ubehjælpsomhed i et politisk felt eller rum uden klar organisering eller spilleregler. Måske er netop det sidste afgørende for, hvordan tv-medierne agerede. På det politiske niveau var der ikke tale om et alternativ mellem to klare og velorganiserede politiske rum. Der var tale om et magtfuldt rum defineret af regimet og et rum, der opstod og udviklede sig undervejs uden klart definerede mål eller retning. Dette kan måske forklare, hvorfor tv så læn-

(C) Forfatteren og Tidsskrift for Islamforskning, ISSN 1901-9580, publiceret 1-03-2013 
ge holdt fast i en mistænkeliggørelse af opstanden, fordi det var en del af ét rum, som de kunne beherske. Et andet rum var ikke eksisterende. Resultatet af denne fastholden af en traditionel strategi i samspil med det politiske styre var, at mange egyptere undervejs helt mistede troen på og tilliden til deres nationale tv. Den gentagne slåen plat eller krone udstiller samtidig det nationale tv's forsatte afhængighed af et veldefineret politisk rum til at navigere i. Tilbage står spørgsmålet derfor, hvorvidt de politiske ændringer har gjort det nationale tv mere lydhørt over for mere pluralistiske stemmer. Ifølge Wolfsfelds perspektiv vil dette først og fremmest afhænge af, hvordan det politiske område i Egypten vil komme til at se ud i de kommende år. Hvis det politiske område bliver mere pluralistisk, er der håb om, at tv også vil blive det. Svaret herpå ligger stadig ude i fremtiden.

\section{Litteratur}

Abu-Lughod, Lila, 2005: Dramas of Nationhood. The Politics of Television in Egypt, The American University in Cairo Press, Cairo.

Alterman, Jon B., 1998: New Media, New Politics? From Satellite Television to the Internet in the Arab World, The Washington Institute for Near East Policy.

Campbell, Heidi A. and Hawk, Diana, 2012: “Al Jazeera's Framing of Social Media During the Arab Spring", i CyberOrient, Vol. 6, Iss. 1, http://www.cyberorient.net/article.do?articleId=7758 (tilgået 03-10-2012).

Certeau, Michel de, 1984: The practice of everyday life. University of California Press.

Galal, Ehab, 2006: "Rum for nye stemmer - Er satellit-tv et demokratisk redskab?", in Jørgen Bæk Simonsen m.fl.: Mellem $\emptyset$ stens ansigter. Modernitet og identitet $i$ det moderne Mellemøsten. Historie-nu, pp. 39-65.

Lynch, Marc, 2006: Voices of the New Arab Public. Iraq, Al-Jazeera, and Middle East Politics Today, Columbia University Press, New York.

Miles, Hugh, 2005: Al-Jazeera. How Arab News Challenged the World, Abacus, London.

El-Nawawy, Mohammed and Khamis, Sahar, 2012: "Political Activism 2.0: Comparing the Role of Social Media in Egypt's "Facebook Revolution" and Iran's "Twitter Uprising"', i CyberOrient, Vol. 6, Iss. 1, http://www.cyberorient.net/article.do?articleId=7439 (tilgået 01-10-2012).

C Forfatteren og Tidsskrift for Islamforskning, ISSN 1901-9580, publiceret 1-03-2013 
Root, Anton, 2012: "Beyond the Soapbox: Facebook and the Public Sphere in Egypt", i CyberOrient, Vol. 6, Iss. 1, http://www.cyberorient.net/article.do?articleId=7751 (tilgået 01-10-2012).

Rugh, William, 2004: Arab Mass Media: Newspapers, Radio, and Television in Arab Politics, Praeger Publishers.

Sakr, Naomi, 2001: Satellite Realms. Transnational Television, Globalization \& the Middle East, I.B. Tauris Publishers, London \& New York.

Sakr, Naomi, 2005: "Maverick or Model? Al-Jazeera's Impact on Arab Satellite Television", in Jean K. Chalaby (ed.): Transnational Television Worldwide. Towards a New Media Order, I.B. Tauris, London \& New York, pp. 66-95.

Sakr, Naomi, 2007: "Approaches to Exploring Media-Politics Connections in the Arab World", in Naomi Sakr (ed.): Arab Media and Political Renewal. Community, Legitimacy and Public Life, I. B. Tauris, London \& New York, pp. 1-12.

Wolfsfeld, Gadi, 1997: Media and political conflict. News from the Middle East, Cambridge University Press, Cambridge.

\section{Forfatterpræsentation}

Ehab Galal er adjunkt i Moderne Islam og Mellemøstlige Studier ved Institut for Tværkulturelle og Regionale Studier, Københavns Universitet. Han er ph.d. fra Københavns Universitet på baggrund af en afhandling om 'Identitet og livsstil på islamisk satellit-tv'. I hans nuværende projekt, undersøger han: "Audience responses to Islamic programming on Arab Television" med feltarbejde blandt arabisktalende seere i fire forskellige lande. Galal har publiceret flere artikler om arabiske medier på både engelsk og dansk; fx "Modern' Salafi broadcasting: Iqra' Channel", i K. Hroub (ed.), Religious Broadcasting in the Middle East (London: C Hurst \& Co Publishers Ltd., 2012); "Transnational Islamic TV: a space for religious and gendered living", i Jakob Egholm Feldt \& Kirstine Sinclair (eds.): 'Lived Space. Reconsidering Transnationalism among Muslim Minorities' (Peter Lang, 2011); "Islamisk satellit-tv og staten" (Islamic satellite-TV and the State) (Babylon, 2011); "The Muslim woman as a beauty queen" (Journal of Arab \& Muslim Media Research, 2010); "Yusuf al-Qaradawi and the New Islamic TV “, i J. Skovgaard-Petersen \& B. Gräf (eds.): 'Global Mufti. The Phenomenon of Yusuf al-Qaradawi' (C Hurst, 2009). Ligeledes har Galal (sammen med Mette Thun $\varnothing$ ) redigeret bogen "Globale medier i verdens brændpunkter. Religion, politik og kultur” (Museum Tusculanum, 2009).

(C) Forfatteren og Tidsskrift for Islamforskning, ISSN 1901-9580, publiceret 1-03-2013 


\begin{abstract}
${ }^{1}$ Selv om jeg i denne artikel ser på perioden fra 25. januar til 11. februar med en perspektivering til tiden efter Mubaraks tilbagetræden, er det ikke ensbetydende med, at de politiske forandringer, der blev resultatet af opstanden, udelukkende kan begrundes i de politiske begivenheder i denne periode. Som andre har belyst, var der i årene op til 2011 voksende krav i den egyptiske befolkning om politiske reformer, ligesom flere politiske aktivistiske bevægelser organiseredes.

${ }^{2}$ Kanalen al-Mihwar ejes af Hassan Raatib, som er en egyptisk forretningsmand.
\end{abstract}

